\title{
Perempuan dan Peribadatan Menurut 1 Timotius 2:9-15
}

\section{Arif Wicaksono, Hendro Hariyanto Siburian}

Sekolah Tinggi Teologi Tawangmangu, Indonesia

Email: erastwicaksono@gmail.com

Diterima: 13 April 2020

Direvisi: 22 Mei 2020

Disetujui: 11 Juni 2020

\begin{abstract}
Abstrak
Kesetaraan Gender antara pria dan wanita adalah masalah yang masih sering diperdebatkan hingga saat ini. Keterlibatan perempuan dalam pelayanan juga masih menuai pro dan kontra di kalangan gereja. Beberapa gereja ada yang menyetujui keterlibatan perempuan dalam peribadatan, namun sebagian gereja masih merasa keberatan akan hal itu. Melihat akan hal ini penulis melalukan penelitian ini dengan menelaah teks 1 Timotius 2:9-15. Metodologi yang penulis gunakan dalam menelaah teks tersebut eksegesis tekstual dengan memerhatikan latar belakang surat, gramatikal dan konteks. Metode ini sangat baik digunakan untuk menguraikan teks tersebut. Dengan menggunakan metode ini diharapkan, pembaca dapat memahami apa yang dimaksudkan Paulus dalam teks1 Timotius 2:9-15 berkaitan dengan Perempuan dan Peribadatan. Pada dasarnya Paulus menulis surat bukan ditujukan untuk memisahkan derajat status sosial antara laki-laki dan perempuan, melainkan justru Paulus sangat menghargai harkat dan martabat perempuan.
\end{abstract}

Kata-Kata Kunci: Kesetaraan gender; Perempuan; Peribadatan.

\section{Abstract}

Gender equality between men and women is a problem that is still often debated to this day. The involvement of women in Ministry is also still there who agree and disagree. Some churches have agreed to the involvement of women in worship, but some churches still object to that. Seeing this, the writer undertakes this research by studying the text of 1 Timothy 2: 9-15. In studying the text the 
writer uses the exegetical method by paying attention to the background of the letter, grammatical and context. This method is very well used to decipher the text. It is hoped that by using this method, the reader can understand what Paul means in the text of 1 Timothy 2: 9-15 relating to Women and Worship. Basically Paul wrote a letter not intended to separate the degree of social status between men and women, but rather Paul really respects the dignity of women.

Keywords: Gender equality; Ministry; Women.

\section{Pendahuluan}

Sikap Protestan terhadap pelayanan-pelayan perempuan tidak banyak didasarkan pada teks-teks Perjanjian Baru seperti pada pendekatan Katolik abad pertengahan. Dalam upaya untuk memberikan struktur yang lebih jelas bagi organisasi mereka, para pemimpin Gereja abad pertengahan atau pada abad keempat mengembangkan pemahaman tentang pelayanan yang banyak dipinjam dari analogi imamat Perjanjian Lama. Pernyataan sebelumnya telah membandingkan Pastor dengan Pendeta, tetapi para penulis ini merumuskan doktrin bahwa Pastor tidak lagi seperti seorang Pendeta, tetapi pada kenyataannya, keduanya adalah sama.

Robert G Clouse mengatakan "Because there was no precedent for women priests in the Old Testament, they were not appointed to such positions within the Christian church. The major ceremonial functions of the church, such as serving communion, were to be performed only by the priests, and consequently women were not allowed to lead these services." Karena tidak ada kehadiran para imam perempuan dalam Perjanjian Lama, maka perempuan tidak ditunjuk untuk posisi-posisi demikian di dalam gereja Kristen. Fungsi seremonial utama gereja, seperti melayani komuni, harus dilakukan hanya oleh para imam, dan akibatnya, Perempuan tidak diizinkan untuk memimpin layanan ini. Pengucilan peranan perempuan dari kepemimpinan dalam persekutuan diperkuat, dengan ajaran bahwa pelayanan adalah peragaan kembali pengorbanan Kristus, menuntut mereka yang memersembahkan korban haruslah laki-laki. ${ }^{2}$ Fakta bahwa para perempuan diduga tercemar oleh periode menstruasi membuat mereka tidak layak untuk terlibat dalam pelayanan ilahi. ${ }^{3}$

${ }^{1}$ Robert G Clouse, Women In Ministry: Four Views (Illinois: Intervarsi1y Press Downers Grove, 1999), 10.

${ }^{2}$ Ibid,

${ }^{3}$ Firman Panjaitan, "Kekerasan Terhadap Istri Dalam Lingkup Domestik (Suatu Tinjauan Etis Kristiani Tentang Kekerasan Terhadap Keluarga)," FIDEI: Jurnal Teologi Sistematika dan Praktika 1, no. 1 (2018): 47-48. 
Kemudian gereja juga menuntut agar pendeta selibat, dan karena itu perempuan dipaksa lebih jauh ke belakang. Para pendeta Kristen tidak banyak berhubungan dengan perempuan karena pertemanan dengan lawan jenis bisa mengarah pada kelekatan romantis. Akibatnya, para imam harus bergantung pada komunitas yang semuanya laki-laki untuk dorongan dan dukungan mereka. Pandangan abad pertengahan tentang perempuan yang dipupuk oleh pandangan tentang pelayanan ini bertentangan. Di satu sisi, perempuan mengenakan alas dan dipuja seperti yang mirip dengan Perawan Maria, tetapi di sisi lain, mereka dipandang sebagai keturunan Hawa yang licik, yang akan memimpin manusia tersesat dengan dosa-dosa daging.

Reformasi Protestan membawa perubahan dalam penafsiran penahbisan. Martin Luther mengajarkan bahwa tidak ada kelas imam khusus tetapi bahwa 'setiap orang adalah imamnya sendiri'. Setidaknya ada dua alasan mengapa Luther mengubah pandangan abad pertengahan tentang pelayanan. Pertama, dia tidak percaya bahwa Tuhan telah menyisihkan sekelompok elit khusus individu yang diberdayakan untuk mematuhi hukum Allah dengan cara tertentu. Kedua, ia berpendapat bahwa tidak ada yang bisa pantas menerima anugerah Allah dengan mematuhi hukum. ${ }^{4}$ Keselamatan diberikan sepenuhnya dan bebas kepada semua orang yang percaya kepada Kristus. Menyangkal kenikmatan fisik, melakukan perbuatan baik, atau melakukan pelayanan keagamaan tidak menghasilkan keselamatan bagi siapa pun.

Mungkin jika Luther bukan seorang revolusioner yang segan, dia akan memberi perempuan peran yang lebih besar dalam pelayanan gereja, tetapi dia tidak melakukannya. Mengikuti langkahnya, Protestan Lutheran dan Reformed (Calvinis) tidak mengizinkan perempuan untuk melayani sebagai pelayan yang ditahbiskan. Namun, baik Luther dan John Calvin mengungkapkan beberapa gagasan tentang perempuan dan pelayanan Kristen yang mungkin telah memengaruhi kelompok-kelompok Protestan untuk memungkinkan partisipasi perempuan dalam posisi kepemimpinan.

\section{Metode Penelitian}

Metode yang digunakan dalam pembahasan adalah deskriptif-analitis. Metode deskriptif adalah metode yang bersifat menjelaskan, menuturkan masalah dengan apa adanya dengan evidensi atau pendapat yang memadai. ${ }^{5}$

${ }^{4}$ Ibid,.

${ }^{5}$ Andreas B Subagyo, Pengantar Riset Kualitatif Dan Kuantitatif (Bandung: Yayasan Kalam Hidup, 2004), 62. 
Metode analitis adalah metode yang memeriksa teks dan menjelaskan dengan menganalitis dan merumuskan gramatikal sehingga makna struktur dapat diyatakan secara tepat. Jadi metode deskriptif-analisis yang dimaksudkan dalam penelitian ini adalah metode yang bersifat menjelaskan, menuturkan konsep berdasarkan teks. ${ }^{6}$ Teks yang dipilih untuk diterapkan adalah 1 Timotius 2:9-15. Teks dianalisis dan diteliti secara terperinci, dengan memeriksa dan merumuskan struktur gramatikal, sehingga pemahaman tentang perempuan dan peribadatan berdasarkan 1 Timotius 2:9-15 dapat dinyatakan dengan tepat dan selanjutnya dapat diimplementasikan secara spesifik dalam konseling Kristen dan pengajaran kristen. Analisis yang digunakan dalam penelitian ini adalah tafsir kritik literer, yang menempatkan teks sebagai sasaran akhir penggalian. Di sini teks diterima sebagaimana adanya, sedangkan berbagai soal yang berkaitan dengan sejarah perkembangan teks sengaja diabaikan sekalipun tidak sepenuhnya. ${ }^{7}$ Kritik literer dipiulih karena metode ini memiliki ciri memberikan perhatian cermat terhadap bahasa. Bahasa, lebih dari sekedar simbol/lambang tetapi merupakan wujud komunikasi yang melibatkan sejumlah dinamika. Metode ini juga pernah dipakai dalam prosedur penarikan kesimpulan, penulis melakukan penalaran induktif berdasarkan analisis data. Menurut Subagyo penalaran induktif adalah menarik kesimpulan logis melalui analisis data. ${ }^{8}$

\section{Pembahasan dan Hasil}

Langkah awal dalam meneliti teks 1 Timotius 2:9-15 adalah dengan menentukan hasil terjemahan, maka selanjutnya adalah menentukan terjemahan yang akan dipergunakan dalam memaknai kata dan kalimat dalam setiap ayat. Penerjemahan teks didasarkan atas beberapa perbandingan varian teks dan tidak lupa memasukan varian dalam bahasa Yunani guna mendekati bahasa aslinya. Adapaun penerjemaah teks 1 Timotius 2:9-15 adalah sebagai berikut:

\section{Translasi I Tim 9: 9-15 9}

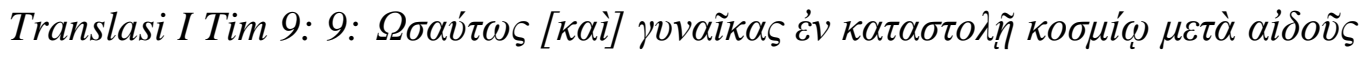

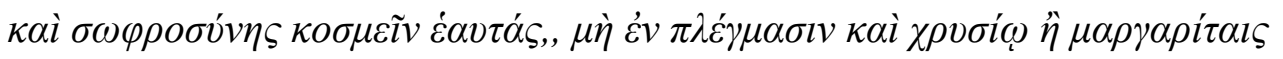

${ }^{6}$ Arif - Wicaksono and Dwi Anggono, "Yesus, Hamba Allah Yang Menderita," FIDEI: Jurnal Teologi Sistematika dan Praktika 2, no. 1 (2019): 147.

${ }^{7}$ Petrus Maryono, Analisis Retoris (Yogjakarta: Andi, 2017), 7.

${ }^{8}$ Maryono, Analisis Retoris.

${ }^{9}$ Translasi adalah terjemahan yang didapatkan dengan melakukan perbandingan antar varian teks dan bahasa asli. Dengan membandingkan varian teks dan bahasa asli diharapkan mendapat pemahaman yang mendekati dari maksud penulis. 


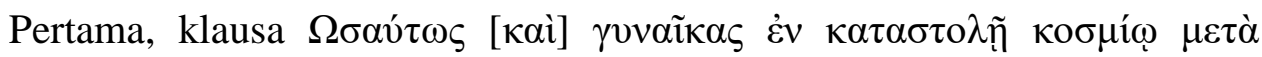

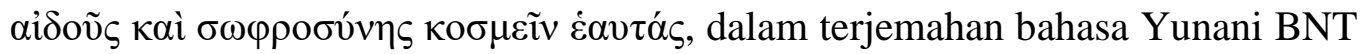
dan BGT memakai bentuk dan struktur yang sama. Dalam terjemahan ASV memakai kata "In like manner, that women adorn themselves in modest apparel, with shamefastness and sobriety" yang artinya "Dengan cara yang sama, perempuan itu menghiasi diri mereka dengan pakaian sederhana, dengan rasa malu dan ketenangan", NAS memakai kata "Likewise, I want women to adorn themselves with proper clothing, modestly and discreetly" yang artinya "Demikian juga, saya ingin perempuan menghiasi diri mereka dengan pakaian yang layak, sopan dan bijaksana", NKJV memakai kata "in like manner also, that the women adorn themselves in modest apparel, with propriety and moderation" yang artinya "dengan cara yang sama pula, bahwa para perempuan menghiasi diri mereka dengan pakaian sederhana, dengan kesopanan dan sikap tidak berlebihan". Sedangkan BIS memakai kata "Hendaklah kaum perempuan menghias dirinya dengan sederhana dan memakai pakaian yang sopan" dan ITB memakai kata "Demikian juga hendaknya perempuan. Hendaklah ia berdandan dengan pantas, dengan sopan dan sederhana". Setelah mengamati dan

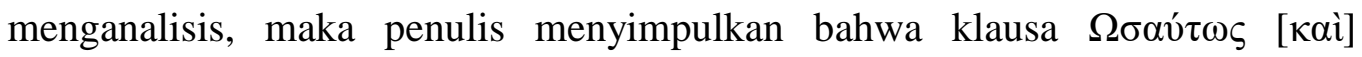

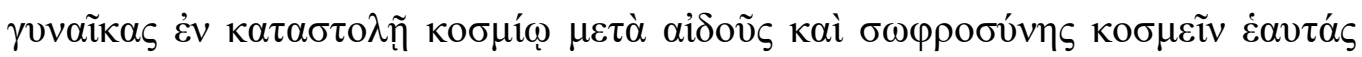
tersebut dapat diterjemahkan menjadi "demikian juga, aku inginkan perempuan menghiasi dirinya dengan pakaian sederhana, dengan rasa malu dan sikap tidak berlebihan".

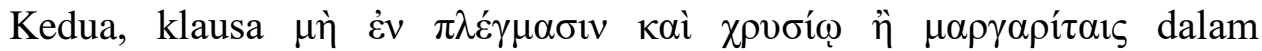
terjemahan bahasa Yunani BNT dan BGT menggunakan bentuk dan struktur yang sama. Dalam terjemahan ASV, NAS dan NKJV memakai kata yang sama "not with braided hair, and gold or pearls" yang artinya "tidak dengan rambut dikepang, dan emas atau mutiara". Dilanjutkan dengan kata ì i $\mu \alpha \tau 1 \sigma \mu \tilde{\varphi}$ $\pi \mathrm{o} \lambda v \tau \varepsilon \lambda \varepsilon 1$, ASV memakai kata "or costly raiment" yang artinya "atau pakaian mahal", NAS memakai kata "or costly garments" yang artinya "atau pakaian mahal", NKJV memakai kata "or costly clothing" yang artinya "atau pakaian mahal". Sedangkan terjemahan BIS memakai kata "Jangan memakai potongan rambut yang menyolok atau perhiasan-perhiasan emas atau mutiara, atau pakaian yang mahal-mahal", dan ITB memakai kata "rambutnya jangan berkepang-kepang, jangan memakai emas atau mutiara ataupun pakaian yang

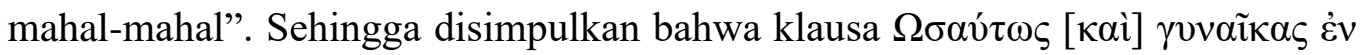

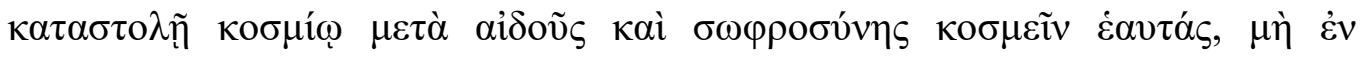

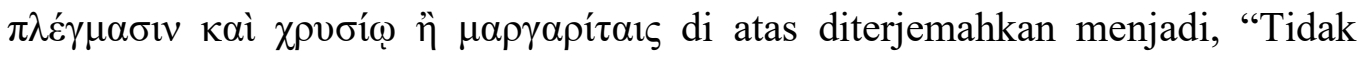


dengan rambut dikepang dengan emas atau mutiara atau pakaian yang mahal". Sehingga terjemahan sementara 1 Timotius 2:9, "Demikian juga, saya ingin perempuan menghiasi dirinya dengan pakaian sederhana, dengan rasa malu dan sikap tidak berlebihan, tidak dengan rambut dikepang dengan emas atau mutiara atau pakaian yang mahal".

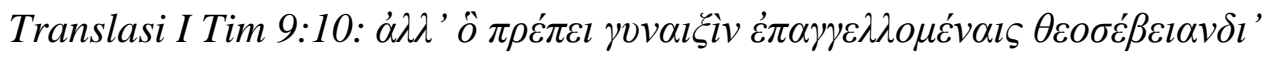
$\tilde{\varepsilon} \rho \omega \omega \nu \dot{\alpha} \gamma \alpha \theta \tilde{\omega} v$

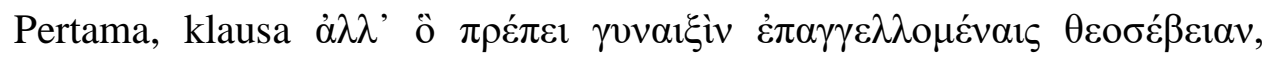
dalam terjemahan bahasa Yunani BGT dan BNT memaki bentuk dan struktur yang sama. ASV memakai kata "but which becometh women professing godliness" yang artinya "tetapi jadilah perempuan yang menyatakan kesalehan", NAS memakai kata "but rather by means of good works" yang artinya "melainkan melalui perbuatan baik", NKJV memakai kata "but, which is proper for women professing godliness" yang artinya "tetapi yang pantas untuk perempuan adalah menyatakan kesalehan". Dalam terjemahan BIS memakai kata, "Sebaliknya, hendaklah Perempuan menghiasi dirinya dengan perbuatanperbuatan yang baik", sedangkan ITB memakai kata "tetapi hendaklah ia berdandan dengan perbuatan baik".

Kedua, klausa $\delta \imath^{\prime}$ '̌́ $\rho \omega v$ à $\gamma \alpha \theta \tilde{\omega} v$, dalam terjemahan bahasa Yunani BNT dan BGT memakai bentuk dan struktur yang sama. Sedangkan dalam terjemahan NKJV memakai kata "with good work" yang artinya "dengan pekerjaan baik", NAS memakai kata "as befits women making a claim to godliness" yang artinya "sebagai perempuan yang membuat pantas menyatakan kesalehan", ASV memakai "through good works" yang artinya "melalui perbuatan baik". Sedangkan dalam terjemahan BIS memakai kata "sebagaimana yang patut bagi perempuan yang beribadat kepada Allah", dan ITB memakai kata "seperti yang layak bagi perempuan yang beribadah". Penulis

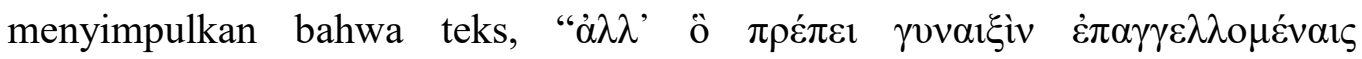

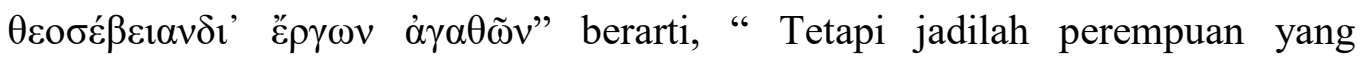
menyatakan kesalehan, sebagai perempuan yang membuat pantas menyatakan kesalehan." Jadi terjemahan sementara 1 Timotius 2:10 "Tetapi jadilah perempuan yang menyatakan kesalehan, sebagai perempuan yang pantas menyatakan kesalehan". 


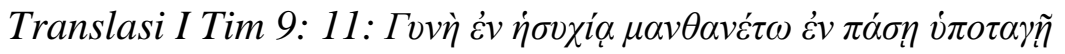

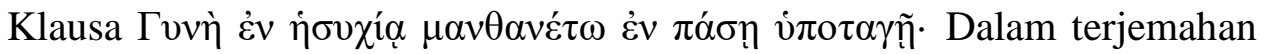
teks Yunani BGT dan BNT memakai bentuk dan struktur yang sama. Dan terjemahan NAS memakai kata "Let a woman quietly receive instruction with entire submissiveness" yang artinya "biarkan perempuan dengan tenang menerima pengajaran dengan seluruh ketundukan", NKJV memakai kata "Let a woman learn in silence with all submission" yang artinya "biarkan perempuan belajar di dalam ketenangan dengan ketundukan", ASV memakai kata "Let a woman learn in quietness with all subjection"yang artinya "biarkan perempuan belajar di dalam ketenangan dengan seluruh penundukkan". Dalam BIS memakai kata "Perempuan harus belajar dengan berdiam diri dan patuh", sedangkan ITB memakai kata "Seharusnya perempuan berdiam diri dan menerima ajaran dengan patuh". Penulis mengambil kesimpulan dari teks ini

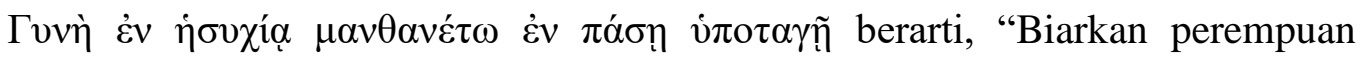
belajar dalam ketenangan dan ketundukan". Sehingga terjemahan Sementara 1 Timotius 2:11, "Biarkan perempuan belajar di dalam ketenangan dan seluruh penundukkan diri"

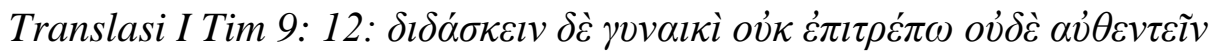

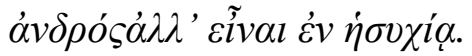

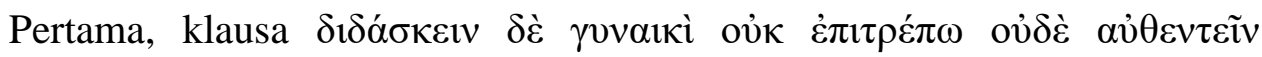
$\grave{\alpha} v \delta \rho o ́ s$, dalam terjemahan teks Yunani BGT dan BNT memakai bentuk dan struktur bahasa yang sama. Dalam terjemahan ASV memakai kata "But I permit not a woman to teach" yang artinya "tetapi saya tidak mengizinkan perempuan untuk mengajar", NKJV memakai kata "And $i$ do not permit a woman to teach or to have authority over a man" yang artinya "Dan aku tidak mengizinkan perempuan untuk mengajar atau memunyai kuasa atas laki-laki", NAS memakai kata "But I do not allow a woman to teach or exercise" yang artinya "tetapi saya tidak mengizinkan seorang perempuan untuk mengajar atau menggerakkan perintah". Sedangkan BIS memakai kata "Saya tidak membenarkan Perempuan mengajar ataupun memerintah laki-laki", dan ITB memakai kata "Aku tidak mengizinkan perempuan mengajar dan juga tidak mengizinkannya memerintah laki-laki".

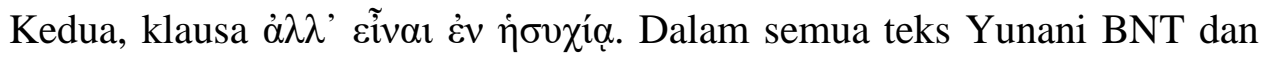
BGT, memakai bentuk dan struktur bahasa yang sama. Perbedaan ditemukan

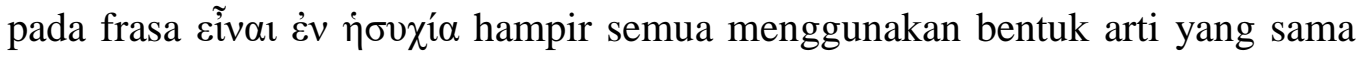
yaitu "tetapi untuk tetap tenang", dalam terjemahan ASV memakai kata "but to 
be in quitness" yang artinya "tetapi tetap berada di ketenangan", NKJV memakai kata "but to be in silence" yang artinya "tetapi tetap berada di dalam diam", NAS memakai kata "but to remain quite" yang artinya "tetapi untuk tetap diam". Sedangkan ITB memakai kata "hendaklah ia berdiam diri", dan BIS memakai kata "mereka harus diam". Disimpulkan oleh penulis daripada teks

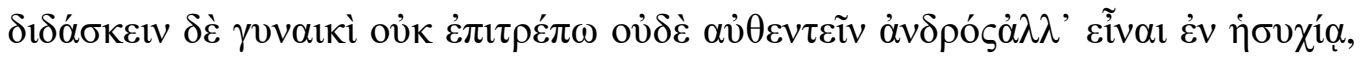
yaitu, "Tetapi aku tidak mengijinkan perempuan untuk mengajar dan berkuasa, tetapi tetap berada di dalam diam" sehingga terjemahan sementara 1 Timotius 2:12, "Tetapi aku tidak mengijinkan perempuan untuk mengajar dan berkuasa atas laki-laki, tetapi hendaklah berada dalam ketenangan".

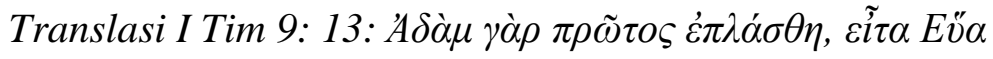

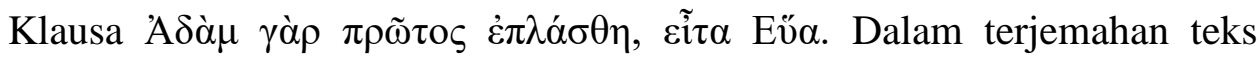
Yunani BGT dan BNT memakai bentuk dan struktur bahasa yang sama. Terjemahan NKJV memakai kata "For Adam was formed first, then Eve" yang artinya "Karena Adam dibentuk terlebih dahulu, kemudian Hawa", ASV memakai kata "For Adam was first formed, then Eve" yang artinya "Karena Adam pertama kali dibentuk, kemudian Hawa", NAS memakai kata "For it was Adam who was first created, and then Eve" yang artinya "Karena Adam yang pertama kali diciptakan, dan kemudian Hawa". Sedangkan BIS memakai kata "Sebab yang pertama-tama diciptakan adalah Adam dan Kemudian baru Hawa" dan ITB memakai kata "Karena Adam yang pertama dijadikan, kemudian barulah Hawa". Sehingga penulis mengambil kesimpulan dari teks klausa Adò $\mu$

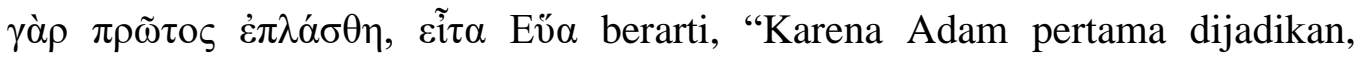
kemudian Hawa" sehingga terjemahan Sementara 1 Timotius 2:13, "Karena Adam pertama kali dibentuk terlebih dahulu, dan kemudian Hawa".

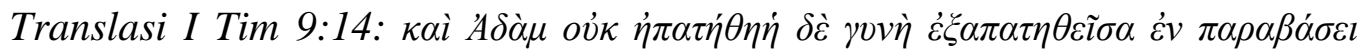

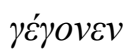

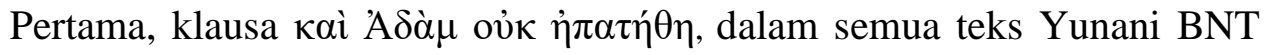
dan BGT, memakai bentuk dan struktur yang sama. NKJV memakai "And Adam was not deceived" yang memunyai arti "Dan Adam tidak tertipu", NAS yang memakai kata "And it was not Adam who was deceived" yang memunyai arti "Dan bukan Adam yang tertipu", sedangkan ASV memakai kata "and Adam was not beguiled" yang diartikan "Dan Adam tidak terperdaya". Dalam terjemahan BIS memakai bentuk "Dan bukannya Adam", dan ITB memakai frasa "Lagipula bukan Adam yang tergoda". Sehingga dapat disimpulkan bahwa 


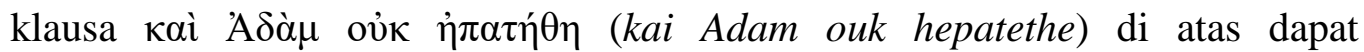

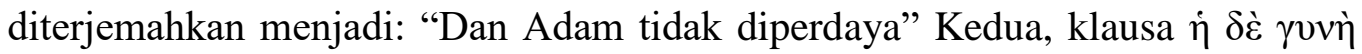

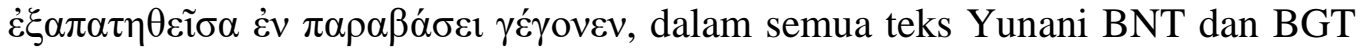
memakai bentuk dan struktur bahasa yang sama. NKJV memakai kata "but the woman being deceived" yang memunyai arti "tetapi perempuan yang tertipu", ASV memakai kata "but the woman being beguiled" yang memunyai arti "tetapi perempuan itu diperdaya", NAS memakai kata "but the woman being quite deceived" yang artinya "tetapi perempuan itu cukup tertipu". Sedangkan BIS memakai kata "melainkan perempuanlah yang tertipu", dan ITB memakai kata "melainkan perempuan itulah yang tergoda". Yang dilanjutkan dengan kata

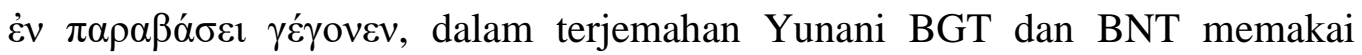
bentuk dan struktur bahasa yang sama. Terjemahan NKJV dan NAS memakai kata "fell into transgression" yang memunyai arti "jatuh ke dalam pelanggaran", sedangkan ASV memakai kata "hath fallen into transgression" yang memunyai arti "telah jatuh ke dalam pelanggaran", BIS memakai kata "sehingga melanggar perintah Allah", dan ITB memakai kata "dan jatuh ke

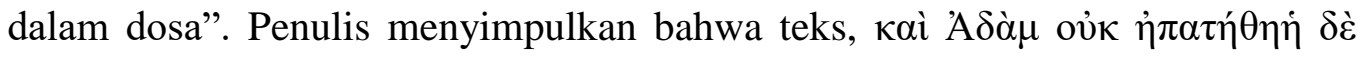

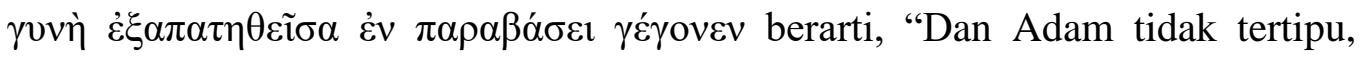
tetapi perempuan itu yang terperdaya dan jatuh ke dalam pelanggaran" sehingga terjemahan Sementara 1 Timotius 2:14, "Dan bukan Adam yang tertipu, tetapi perempuan yang tertipu dan telah jatuh ke dalam pelanggaran".

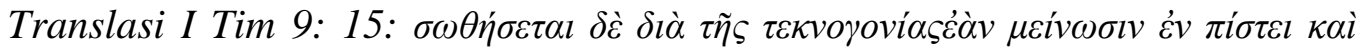

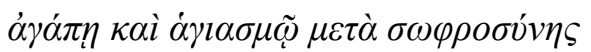

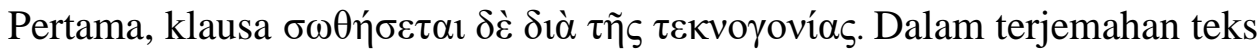
Yunani BNT dan BGT memakai bentuk dan struktur bahasa yang sama. Terjemahan NKJV memakai kata "Nevertheless she will be saved in childbearing" yang memunyai arti "namun dia akan diselamatkan dari melahirkan anak", ASV memakai kata "but she shall be saved through her child-bearing" yang memunyai arti "tetapi dia akan diselamatkan melalui melahirkan anak", NAS memakai kata "But women shall be preserved through the bearing of children" yang artinya "tetapi perempuan harus dipelihara melalui melahirkan anak". Sedangkan BIS memakai kata "Meskipun begitu, perempuan akan selamat dengan melahirkan anak", dan ITB memakai kata "Tetapi perempuan akan diselamatkan karena melahirkan anak".

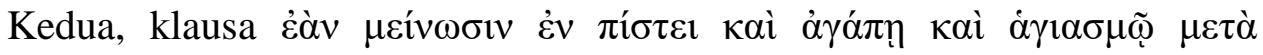

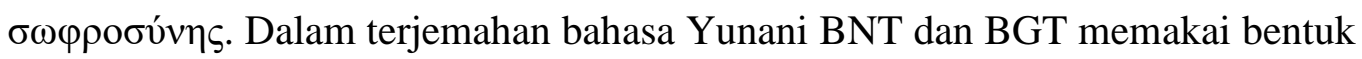


dan struktur bahasa yang sama. Dalam terjemahan NKJV memakai kata"if they continue in faith, love, and holiness, with self-control" yang memunyai arti "jika mereka terus dalam iman, kasih, dan kekudusan, dengan pengendalian diri", ASV memakai kata "if they continue in faith and love and sanctification with sobriety" yang memakai arti "jika mereka terus dalam iman dan cinta dan pengudusan dengan ketenangan hati", NAS memakai kata "if they continue in faith and love and sanctity with self-restraint" yang memunyai arti "jika mereka terus dalam iman dan cinta dan kesucian dengan pengendalian diri”. Sedangkan dalam terjemahan BIS memakai kata "asal ia dengan kerendahan hati tetap percaya kepada Kristus dan tetap mengasihi orang lain serta hidup khusus untuk Allah", dan ITB memakai kata "asal ia bertekun dalam iman dan kasih dan pengudusan dengan segala kesederhanaan”. Sehingga penulis mengambil

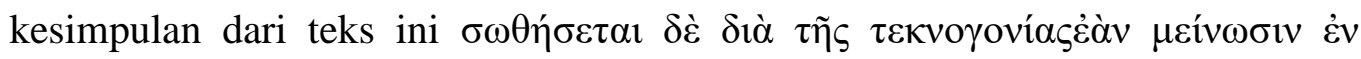

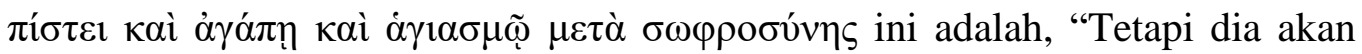
selamat melalui melahirkan anak jika mereka terus dalam iman dan cinta dan pengudusan dengan ketenangan hati”. Sehingga terjemahan sementara 1 Timotius 2:15, "Namun ia akan diselamatkan melalui melahirkan anak, jika ia terus dalam iman dan kasih dan pengudusan dengan ketenangan hati".

\section{Analisis Literer}

Analisis Literer Teks 1 Timotius 2:9

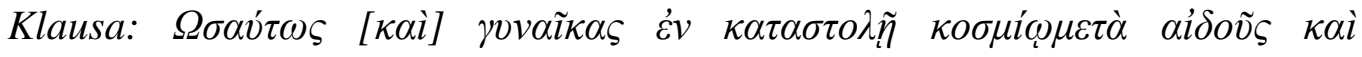

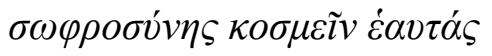

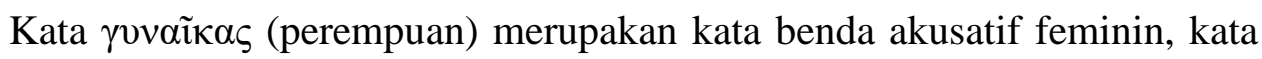

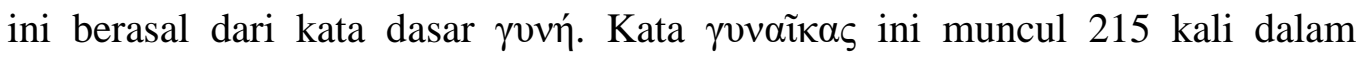
Alkitab. Fungsi akusatifnya di sini untuk memberikan batasan akhir bagi suatu tindakan, yaitu berfungsi sebagai penderita atau objek langsung. Sedangkan kata $\kappa \alpha \tau \alpha \sigma \tau \mathrm{\nu} \lambda \tilde{n}$ (pakaian), berbentuk kata benda datif feminin tunggal common, yang

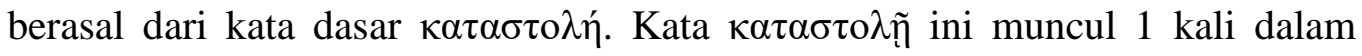
Alkitab, kata ini adalah berbentuk kata benda datif yang menjelaskan kata benda inti di kalimat berikutnya. Datif adalah menjelaskan kasus dari kata benda sebagai subjek yaitu $\kappa \alpha \tau \alpha \sigma \tau \mathrm{o} \lambda \tilde{\eta}$ (pakaian) ${ }^{10}$. Kata $\kappa \alpha \tau \alpha \sigma \tau \mathrm{\lambda} \lambda \tilde{\eta}$ ini berkaitan dengan kata $\dot{\varepsilon} v$, yang berbentuk preposition. Fungsi preposition ini untuk

${ }^{10}$ https://www.studylight.org/commentaries/bnb/1-timothy-2.html. 
menunjukkan hubungan antara dua hal. Preposition sebagai kata tengah, dengan kala akusatif untuk menjelaskan objek yang terjadi selama-lamanya. ${ }^{11}$

Kebanyakan penulis menginterpretasi Paulus bahwa laki-laki hanya diperuntukkan untuk berdoa dan mengajar perempuan mengenai pakaian saja dan hal itu sangat bertentangan dengan ajarannya. Meskipun doa Sinagoga hanya diperuntukkan untuk laki-laki dan bukan perempuan, namun perempuan diperintahkan untuk berdiam diri dan belajar mengenai hal-hal tertentu saja, bukan untuk berdoa.12

Kata mereka harus "berpakaian sopan". Ekspansi frasa yang digunakan di sini adalah: "menghiasi diri mereka dengan pakaian sederhana". Peringatan ini masih harus dilakukan sampai saat ini. Kata "kesopanan" menunjukkan kesederhanaan yang tidak melampaui batas pada seorang perempuan. Hal ini dapat dimengerti dengan melihat budaya yang ada pada waktu itu. Tempat dimana Timotius melayani adalah kota Efesus yang memiliki kuil-kuil penyembahan kepada Dewi Aprodite. Di dalam Kuil Aprodite terdapat adanya banyak pelacur bakti yang ditempatkan guna menarik sebanyak mungkin orang beribadah dalam kuil. Tidak heran jika kuil ini dianggap menawarkan kepuasan jasmani dan rohani, bahkan penyembahan kepada Aprodite layaknya "wisata seks". ${ }^{13}$ Kebiasaan para pelacur bakti pada waktu itu untuk menarik perhatian pengunjung dengan mendadani dirinya secara mencolok, mengepang rambutnya, menggunakan perhiasan-perhiasan dan pakaian yang tidak sopan. Hal ini dilakukan sebagai daya tarik memikat sebanyak mungkin pengunjung.

Perempuan harus berpakaian dengan penuh "kesopanan", kata tersebut menunjukkan penilaian yang baik pada perempuan. ${ }^{14}$ Sangat besar kemungkinan, nasehat ini muncul bukan untuk mendiskreditkan perempuan melainkan menyelamatkan perempuan menghindari prasangka buruk bahwa mereka sama seperti pelacur bakti yang ada di dalam kuil dewi Aprodite.

Perempuan yang menganut agama Kristen haruslah rendah hati, bijaksana, pendiam, dan patuh. Mereka harus sangat rendah hati dalam pakaian mereka, karena perempuan memiliki ornamen baik dalam dirinya yang dengannya mereka harus menghiasi diri mereka sendiri. Pekerjaan baik adalah ornamen

${ }^{11}$ Ferdinan Suawa, Memahami Gramatika Dasar Bahasa Yunani Koine (Bandung: Kalam Kudus, 2009), 39.

${ }^{12}$ David H Stern, Jewish New Testament Commentary (USA: Jewish New Testament Publications, INC, 1996), 639.

${ }^{13} \mathrm{https} / / /$ www.bbc.com/indonesia/vert-cul-37778395 diakses 30 Maret 2020

${ }^{14}$ Kenneth L Barker and John R Kohlenberger III, NIV Bible Commentary (USA: Zondervan Publishing House, 1994), 897. 
terbaik, perempuan yang mengaku saleh harus sopan dalam berpakaian, dan juga dalan hal-hal lain, serta memunyai profesi yang baik. Para perempuan harus belajar asas-asas mengenai agama, memelajari Kristus, serta memelajari Kitab Suci. Seorang perempuan harus diam, tunduk, dan tidak berkuasa atas lakilaki. $^{15}$

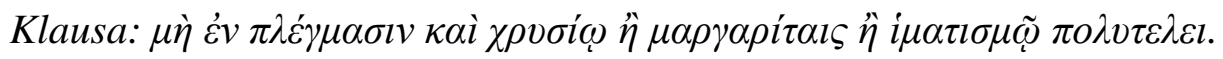

Kata $\pi \lambda \dot{\varepsilon} \gamma \mu \alpha \sigma ı v$ (mengepang rambut), merupakan kata benda datif. Berasal dari kata $\pi \lambda \varepsilon \dot{\gamma} \mu \alpha$. Kata ini muncul 1 kali dalam Alkitab. Fungsi datif di sini untuk mendeskripsikan kata benda atau kata yang akan mewujudkan sesuatu. Kata $\pi \lambda \dot{\varepsilon} \gamma \mu \alpha \sigma \mathrm{v}$ secara harfiahnya dapat diterjemahkan "mengepang rambut". BIS memberi arti "memakai potongan rambut yang mencolok". Dalam teks Yunaninya kata "mengepang rambut" mengandung banyak arti, namun dalam konteks ini berarti "menjalin rambut".

Tulisan-tulisan Yahudi memperingatkan terutama tentang godaan seksual yang terlibat dalam perhiasan tersebut; penulis Yunani juga mengutuk perempuan kaya yang memamerkan perhiasan mahal mereka. Dalam tradisi Yahudi sering ditemui seorang perempuan dengan rambut dikepang dengan emas dan mutiara-mutiara, hal tersebut yang mungkin dilihat oleh Paulus di sini bahwa laki-laki tertarik oleh rambut perempuan yang dihiasi, harus dipahami disini bahwa Paulus ingin memeringatkan kepada perempuan mengenai kelebihan tersebut yang dianggap tidak sopan pada kebudayaan saat itu, bukan sebagai aturan terhadap semua perhiasan yang dikenakan oleh perempuan. ${ }^{16}$

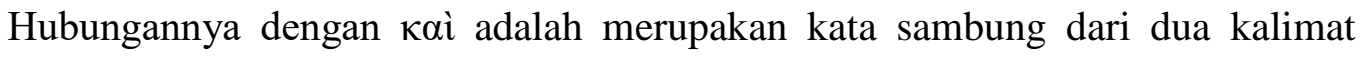

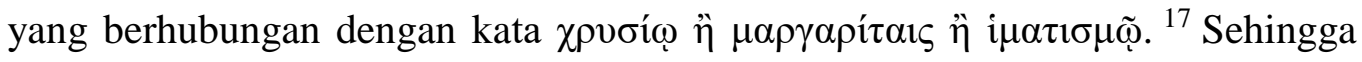
dapat dijelaskan bahwa kata benda dapat menyatakan tentang suatu bentuk kata yang menjadi induk kalimat sebenarnya. ${ }^{18}$

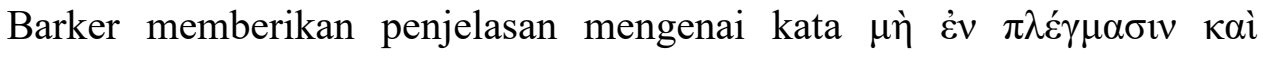

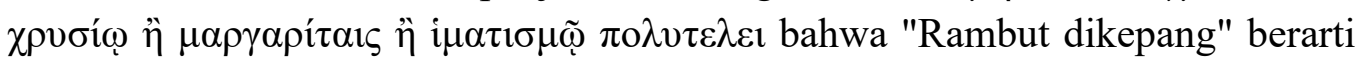
rambut yang dijalin atau dikepang. Perempuan Kristen sebaiknya tidak menghiasi dirinya dengan "emas atau mutiara atau pakaian mahal" untuk

${ }^{15}$ Matthew Henry, Commentary In One Volume (USA: Regency Reference Library, 1961), 1889.

${ }^{16}$ Henry, Commentary In One Volume.

${ }^{17} \mathrm{https}: / / \mathrm{www}$. studylight.org/commentaries/hmc/1-timothy-2.html.

${ }^{18}$ Lyne Newel, Bahasa Yunani Koine (Malang: SAAT, 1987), 56. 
menarik perhatian pada dirinya sendiri. Karena hal tersebut merupakan cara yang sering dilakukan pelacur untuk menarik perhatian orang lain.

Tindakan menjalin rambut dengan perhiasan mahal juga dapat menunjukkan kesombongan dan keegoisan bagi seorang perempuan, dan sangat bertentangan dengan semangat kristiani. Tindakan tersebut dapat mendatangkan kesenjangan sosial bagi perempuan kaya dan miskin. Jika hal ini dipertahankan pada masa itu pastinya akan berpengaruh rusaknya hubungan seorang dengan yang lain. Apalagi dalam konteks beribadah hal ini akan sangat mengganggu.

Seorang perempuan Kristen harus menghiasi diri mereka sendiri dengan perbuatan baik, sesuai untuk perempuan yang mengaku menyembah Tuhan. Perempuan harus mengekspresikan imannya melalui perbuatan baik. Hal ini sangat dominan dalam surat-surat Pastoral daripada surat-surat Paulus sebelumnya oleh karena kebutuhan jemaat saat itu. ${ }^{19}$

Analisis Literer Teks 1 Timotius 2:10

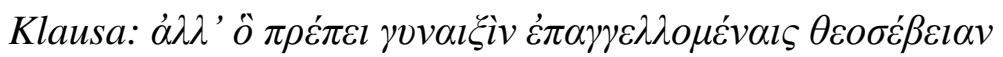

Kata $\pi \rho \varepsilon ́ \pi \varepsilon ı$ (sebaiknya), berbentuk kata kerja yang berasal dari kata dasar $\pi \rho \dot{\pi} \pi \omega$, yang akan menjelaskan kata kerja atau kata aktif. Pemakaian kata $\pi \rho \dot{\pi} \pi \varepsilon \iota$ muncul 215 kali dalam Alkitab. Kata ini berbentuk kata kerja, orang ke-3, aktif dan indikatif tunggal. Bentuk aktifnya menunjukkan perempuan-perempuan (subjek) sebagai penderita. Yang menjelaskan verb inti di kalimat berikutnya. Orang ke-3 menjelaskan tentang siapa yang mengalami hal tersebut, indikatif menjelaskan waktu sekarang ini, dan kata ini bersifat aktif yang menyatakan tentang penderita. Bentuk kata aktif dari kata $\pi \rho \varepsilon ́ \pi \varepsilon ı ~ m e n u n j u k k a n ~ k e p a d a$ perempuan-perempuan Kristen di Efesus sebagai pelaku (subjek), bentuk indikatifnya memberikan suatu kewajiban untuk dilakukan sekarang yang memberikan penjelasan mengenai subjek sebagai pelaku. Klausa ini menunjukkan kepada siatuasi perempuan-perempuan pada saat itu yang senang menghiasi tubuhnya dengan perhiasan-perhiasan. Tulisan-tulisan Yahudi seringkali memeringatkan terutama tentang godaan seksual yang terlibat dalam perhiasan tersebut; Penulis Yunani juga mengutuk perempuan kaya yang memamerkan perhiasan mahal mereka. ${ }^{20}$

\footnotetext{
${ }^{19}$ Barker and Kohlenberger III, NIV Bible Commentary.

${ }^{20}$ Craig S Keener, Bible Background Commentary (USA: Iter Varsity Press, 1993), 610
} 611. 
Klausa: $\delta \imath^{\prime}$ है $\rho \gamma \omega v \dot{\alpha} \gamma \alpha \theta \tilde{\omega} v$

Kata है $\gamma \gamma \omega v$ (pekerjaan), merupakan bentuk kata benda, genitif, neuter, plural, common, yang berasal dari kata dasar ěpyov, kata ini muncul 169 kali di dalam Alkitab, fungsi genetifnya untuk memberikan arti daripada suatu kalimat yang menjadi objek. Yaitu $\delta \imath^{\prime}$ (melewati) sebagai kata sambung yang bersifat

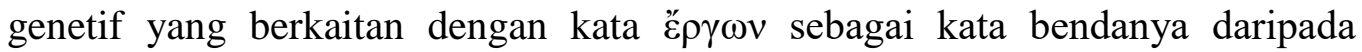
objek. NKJV menerjemahkannya "dengan kerja bagus", ASV menerjemahkan sebagai "melalui perbuatan baik", sedangkan NAS memertegas dengan "membuat klaim dengan kebaikan".

Dengan perbuatan baik yang membuat perempuan mengaku saleh, "dengan perbuatan baik" artinya, tidak pantas bagi yang mengaku sebagai pengikut Kristus, untuk mendandani dirinya dengan berlebihan. Paulus lebih menekankan pentingnya kecantikan dari dalam dibandingkan kecantikan luar karena penggunaan dandanan dan perhiasan yang berlebihan. Apalagi penggunaan perhiasan untuk memamerkan kekayaan yang berpotensi mendatangan kesenjangan sosial dalam beribadah. Kebanggaan-kebanggan terhadap perhiasan dan dandanan yang berlebihan juga dapat menjerat manusia terikat kepada perkara-perkara duniawi. Jika mereka adalah orang Kristen, mereka tidak perlu melakukan hal-hal kesombongan seperti itu, dan memfokuskan hati pada realitas yang lebih substansial. Mereka adalah pengikutpengikutNya yang mengaku "yang melakukan kebaikan," dan kinerja dari perbuatan baik khususnya menjadi bagian dalam diri mereka.

Perempuan yang mengaku telah menetapkan kasih sayang pada Tuhan sebagai Juru Selamat mereka, seharusnya tidak ada didalamnya untuk mencari ornamen seperti yang akan menunjukkan bahwa hati mereka sangat terikat pada hal-hal duniawi. Perbuatan baik, atau perbuatan kebajikan, harus ada pada diri perempuan Kristen. Sifat perempuan tampaknya disesuaikan dengan kinerja semua perbuatan yang menuntut kebaikan, kelembutan, dan kelembutan perasaan; dari semua yang berasal dari belas kasihan, simpati, dan kasih sayang. Secara naluriah tindakan kuat dan berani dalam tujuan yang baik seorang pria Kristen, ada sesuatu yang sangat sesuai dengan karakter perempuan dalam tindakan simpati dan kebajikan yang rendah hati dan tidak mencolok. Tuhan tampaknya telah membentuk pikirannya untuk hal-hal seperti itu saja, dan dalam 
hal-hal seperti itu ia menempati ruang yang tepat alih-alih dalam mencari hiasan luar. $^{21}$

Teks ini sesungguhnya tidak sedang melarang perempuan memiliki perhiasan, atau melarang untuk perempuan berdandan. Konteks pertemuan ibadah yang melatarbelakangi teks memungkinkan bahwa pengunaan perhiasan dan dandanan yang berlebihan akan memicu persoalan bagi umat yang sedang beribadah. Persoalan tersebut dapat berupa kecemburuan, penilaian perempuan yang terikat keduniawian, ataupun penyamaan perempuan kristen dengan perempuan dalam konteks kuil aprodite. Nasehat ini perlu dipahami sebagai usaha Paulus untuk menjaga jalannya ibadah dapat dilaksanakan dengan tertib dan teratur tanpa sandungan.

\section{Analisis Literer Teks 1 Timotius 2:11}

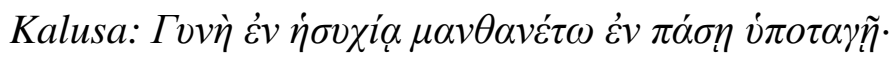

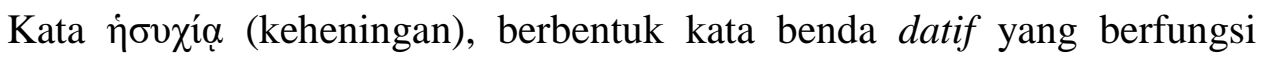
untuk mendeskripsikan kata benda atau kata yang akan mewujudkan sesuatu.

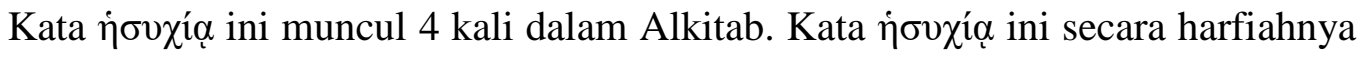
dapat diterjemahkan "keheningan". ITB memberi arti "berdiam diri". Dalam teks Yunaninya kata "keheningan". Dalam teks Yunaninya kata "keheningan" mengandung banyak arti, namun dalam konteks ini berarti "dalam diam". ${ }^{2}$

Paulus memberi tahu para perempuan dalam jemaat di Efesus bahwa mereka tidak diperkenankan untuk berbicara keras-keras dalam ruang umum, di sini Paulus mengatakan bahwa mereka harus "belajar dengan tenang dan tunduk sepenuhnya". Kata "penyerahan" bukan berarti menyerahkan pikiran dan hati nurani seseorang atau meninggalkan penilaian pribadi seseorang. Namun hal itu berarti, bahwa seorang perempuan harus tunduk kepada suaminya meskipun hal tersebut dapat memiliki aplikasi yang lebih luas dari penyerahan kepada para pejabat dan peraturan gereja. ${ }^{23}$

Paulus melanjutkan dengan mengatakan, "Saya tidak mengizinkan perempuan untuk mengajar atau memiliki otoritas atas pria". Masalah yang terjadi saat itu adalah perempuan tidak diperbolehkan untuk mengajar, karena kebanyakan dari perempuan saat itu tidak mendapatkan pendidikan mengenai ajaran-ajaran iman selayaknya kaum laki-laki. Jika perempuan yang tidak

\footnotetext{
${ }^{21}$ https://www.studylight.org/commentaries/bnb/1-timothy-2.html. Diakses pada tanggal 04 Maret 2019, Pukul 13.25 WIB.

${ }^{22}$ Barker and Kohlenberger III, NIV Bible Commentary.

${ }^{23}$ Ibid.
} 
pernah mendapatkan pembekalan ajaran-ajaran dasar mengajar, sudah pasti hal ini dapat memunculkan ajaran-ajaran yang tidak sesuai dengan ajaran yang sehat.

Untuk aturan perempuan tidak diperbolehkan untuk memiliki otoritas atau kuasa di atas laki-laki, ini berkaitan dengan hubungan dalam keluarga. Terjadi kecenderungan dalam keluarga waktu itu perempuan-perempuan yang telah menjadi Kristen dan suami mereka belum menjadi kristen, perempuanperempuan tersebut memperlakukan suami mereka dengan tidak baik. Tidak dipungkiri Paulus sangat menghargai fakta bahwa Timotius sendiri telah diajari cara yang benar oleh ibu dan neneknya yang saleh. Dia juga menulis kepada Titus bahwa para perempuan yang lebih tua selalu memikul tanggung jawab utama untuk mengajar anak-anak, baik di sekolah, rumah maupun di gereja. ${ }^{24}$ Namun tidak pernah ditemui adanya perempuan yang diijinkan berkuasa atau memerintah suami mereka yang belum percaya. Perempuan-perempuan ini memiliki kewenangan untuk mendidik anak-anaknya, namun tidak terhadap suami mereka.

\section{Analisis Literer Teks 1 Timotius 2:12}

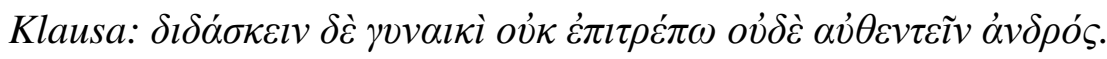

Kata $\delta ı \delta \alpha ́ \sigma \kappa \varepsilon ı v$ (untuk mengajar), merupakan bentuk kata kerja, infinitif, present, aktif. Kata ini berasal dari kata dasar $\delta ı \alpha ́ \sigma \kappa \omega$, yang muncul 97 kali di dalam Alkitab. Fungsi present infinitif adalah untuk menyatakan suatu perbuatan yang terus menerus atau berulang kali, infinitif juga sering dipakai untuk melengkapi kata-kata kerja tertentu dalam suatu kalimat. Kata ini berhubungan dengan dengan kata $\delta \grave{\varepsilon}$, sebagai kata penghubung terhadap kata

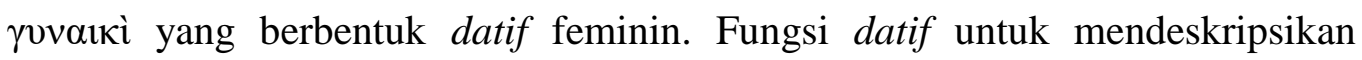
$\dot{\varepsilon} \pi \imath \rho \varepsilon \dot{\pi} \omega$, sebagai kata kerja aktif.

Orang yang memuridkan orang lain bertanggung jawab atas kehidupan dan pertumbuhan rohani mereka, perempuan tidak harus memiliki tanggung jawab semacam itu untuk laki-laki terutama suami mereka, mereka hanya diijinkan kepada anak mereka saja. Meskipun perempuan dapat belajar dengan cara yang sama seperti laki-laki, Paulus tidak mengizinkan perempuan untuk mengajar (untuk memuridkan) pria atau menggunakan otoritas pendisiplin atas dirinya. $^{25}$

\section{${ }^{24}$ Ibid.}

${ }^{25}$ David H Stern, Jewish New Testament Commentary (USA: Jewish New Testament Publications, 1992), 639-640. 


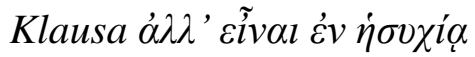

Kata eĩvor (saya), berbentuk kata kerja yang berasal dari kata dasar cỉuí, yang akan menjelaskan kata kerja atau kata aktif. Pemakaian kata Eĩvol muncul 2461 kali dalam Alkitab. Bentuk kata kerja ini disertakan dengan kasus aktif yang bersifat objek langsung. Kata eĩvor ini berkaitan dengan kata $\dot{\alpha} \lambda \lambda$ ', yang berbentuk preposition sebagai kata hubung. Kata $\dot{\alpha} \lambda \lambda$ ' cĩvol ini berkaitan dengan kata $\dot{\varepsilon} v$, yang berbentuk kata preposition. Fungsi preposition ini menunjukkan hubungan antara dua hal. Preposition sebagai kata depan dengan kala datif untuk menjelaskan, fungsi datif ialah menjelaskan kasus dari kata benda sebagai

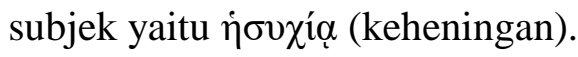

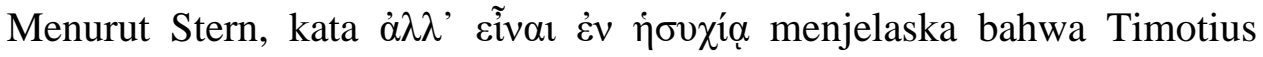
harus membiarkan seorang perempuan belajar (didisiplinkan) dengan damai, tanpa merasa terganggu. Pengertiannya bukanlah "dalam keheningan", seperti dalam kebanyakan terjemahan yang menyiratkan bahwa ia harus tutup mulut, tetapi "diam". ${ }^{26}$

\section{Analisis Literer Teks 1 Timotius 2:13}

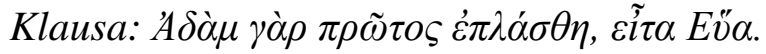

Kata $\dot{\varepsilon} \pi \lambda \alpha ́ \sigma \theta \eta$ (membuat), merupakan kata kerja, indikatif, pasif yang berasal dari $\pi \lambda \alpha \dot{\sigma} \sigma \omega \omega$, kata ini muncul 2 kali dalam Alkitab. Fungsi indikatifnya sebagai penunjuk suatu tindakan yang benar-benar terjadi atau menggambarkan tindakan yang diterima oleh subjek sekarang ini. Kata ini berhubungan dengan

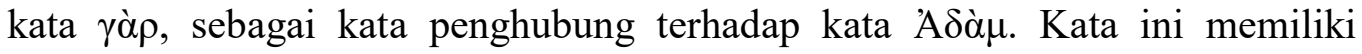
kesejajaran dengan dengan teks Kejadian 2:18. Yang dimaksud di sini ialah kisah pada saat Tuhan menciptakan manusia Adam lah yang pertama kali diciptakan baru setelah itu Hawa. Dan yang dinyatakan oleh beberapa beberapa

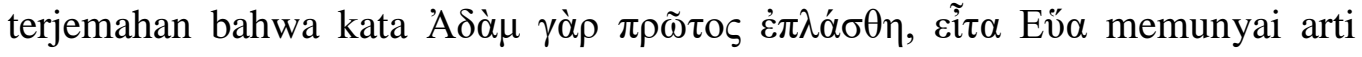
dalam terjemahan ASV sebagai "Karena Adam pertama kali dibentuk, kemudian Hawa", NAS "Karena Adam pertama kali diciptakan, dan kemudian Hawa", NKJV "Karena Adam dibentuk terlebih dahulu, kemudian Hawa".

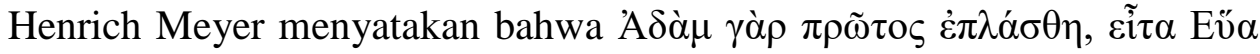
merupakan alasan untuk larangan sebelumnya, yang diambil dari sejarah penciptaan. Surat-surat Paulus merupakan bukti historis dari kitab Perjanjian Lama bagi Rasul Paulus, yang penuh dengan makna simbol dari kebenaran

${ }^{26}$ Stern, Jewish New Testament Commentary. 
universal yang tinggi. ${ }^{27}$ Jadi di sini, fakta bahwa Adam yang pertama kali diciptakan, dan bahwa Hawa yang tergoda oleh ular bukan Adam merupakan prototipe dan bukti bahwa hal tersebut bukan ditujukan untuk seorang istri, tetapi untuk menjadi bawahan yang patuh kepada suami.

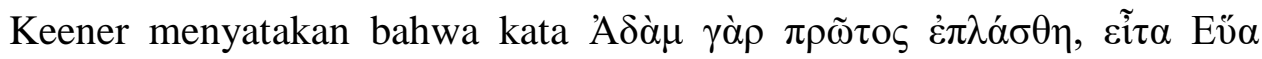
merupakan pernyataan Paulus yang menganggap bahwa subordinasi perempuan dalam peran pastoral memunyai dasar dari urutan penciptaan, beberapa penulis menganggap argumennya digunakan secara universal dan untuk semua keadaan. Namun penulis yang lain menganggap pernyataan Paulus di sini hanya sebagai perbandingan sementara. $^{28}$

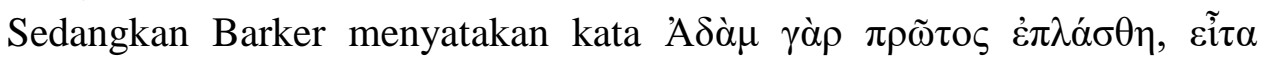
Eűabahwa peran istri yang tunduk kepada suaminya melekat dalam penciptaan. Adam diciptakan terlebih dahulu, dan kemudian Hawa (Kejadian 2: 21-23, di mana Allah membuat Hawa dari tulang rusuk yang diambil dari Adam). Terdapat banyak komentator yang telah mencatat mengenai kisah ini bahwa Hawa tidak dibuat keluar dari kepala Adam untuk memerintah dia, atau keluar dari kakinya untuk diinjak-injak olehnya, tetapi dari sisinya harus sama dengan dia dan dekat hatinya untuk dicintai oleh dia. Hal tersebut mengekspresikan dengan sempurna kehidupan yang ideal dari suatu pernikahan yang bahagia. Suami yang memiliki konsep ini biasanya akan menemukan istrinya yang ingin menyenangkannya. ${ }^{29}$ Untuk mengilustrasikan prinsip kepemimpinan maskulin, Paulus mengutip urutan penciptaan sebagai penetapan kodrat kepemimpinan laki-laki (I Kor 11:8,9). ${ }^{30}$

\section{Analisis Literer Teks 1 Timotius 2:14}

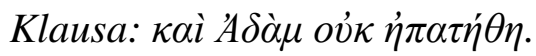

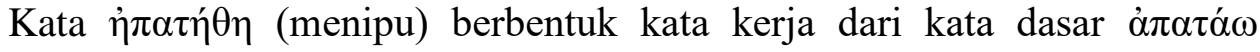
dengan kasus indikatif aorist passive orang ketiga singular. Hubungan dengan

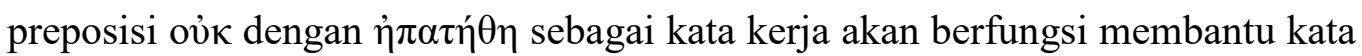
kerja tersebut menyatakan fungsi kasusnya, sehingga NAS memakai kata "who was deceived" (yang menghasut). Kata menipu tersebut menunjukkan sesuatu yang telah terjadi atau lampau. J. Wesley Brill berpendapat bahwa Hawa tertipu

\footnotetext{
${ }^{27}$ https://www.studylight.org/commentaries/hmc/1-timothy-2.html. Diakses pada tanggal 1 Maret 2019. Pukul 08.08 WIB

${ }^{28}$ Keener, Bible Background Commentary.

${ }^{29}$ Barker and Kohlenberger III, NIV Bible Commentary.

${ }^{30}$ Everett F Harrison, Tafsiran Alkitab Wycliffe (Malang: Gandum Mas, 2001), 869.
} 
oleh setan dan telah jatuh ke dalam dosa. Setan mengetahui bahwa perempuan lemah, oleh sebab itu setan mencobai dia, bukan Adam. Maka bukan Adam yang ditipu oleh setan. ${ }^{31}$ Pemakaian kata $\grave{\pi} \alpha \tau \eta \dot{\theta \eta}$ (menghasut) muncul 3 kali di dalam Alkitab, di antaranya terdapat kesejajaran bentuk dalam teks Efesus 5:6 ( $\dot{\alpha} \pi \alpha \tau \dot{\alpha} \tau \omega)$, sedangkan dalam teks Yakobus 1:26 $\dot{\alpha} \pi \alpha \tau \tilde{\omega} v$.

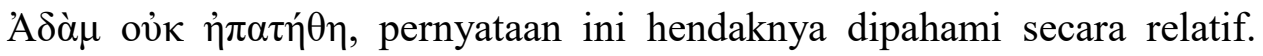
Adam tergoda juga, tetapi tidak semutlak Hawa. Kata Yunani yang sama dipakai untuk perempuan, namun dalam bentuk yang lebih intensif. Adam langsung mengikuti jejak Hawa dan bukan memanfaatkan kepemimpinannya untuk melawan gagasan Hawa. ${ }^{32}$

Pada ayat ini Paulus merujuk pada kisah kejatuhan Hawa seperti yang telah diceritakan dalam Kejadian 3, beberapa kisah Yahudi telah memerdalam rasa bersalah atau tipu daya yang telah dilakukan oleh Hawa. Bahwa kisah-kisah Yahudi telah membandingkan perempuan-perempuan yang tidak terpelajar di dalam gereja dengan perempuan yang terpelajar. Dalam surat-surat Paulus sebelumnya di dalam Korintus telah membandingkan seluruh gereja Korintus, baik laki-laki maupun perempuan (2 Korintus 11:3). Paulus telah menerapkan ilustrasi mengenai kejatuhan Hawa kepada semua perempuan di sepanjang masa. Kemungkinan ia telah menyiratkan bahwa semua perempuan lebih mudah untuk ditipu oleh laki-laki, dan ilustrasi dalam 2 Korintus 11:3 akan hilang, karena guru-guru palsu tersebut merupakan seorang laki-laki. ${ }^{33}$

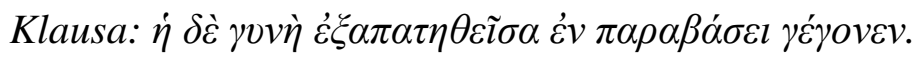

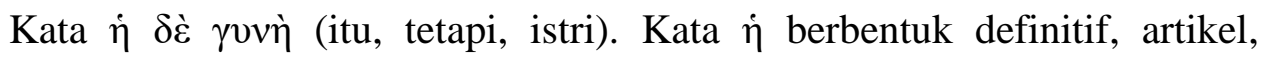
nominatif, feminin tunggal. Kata artikel ini tidak selalu muncul dalam bentuk kata, namun kata artikel ini berhubungan dengan kata benda yakni yang berjenis, berkelamin, dan berkasus yang sama dengan kata benda yang mengidentifikasikan kata tersebut. Kata $\dot{\eta}$ berasal dari kata o, kata ini muncul 982 kali dalam Alkitab. Kata $\dot{\eta}$ berhubungan dengan kata $\delta \grave{\varepsilon}$ sebagai konjungsi kata depan. Dan fungsinya konjungsi adalah untuk menunjukkan kata

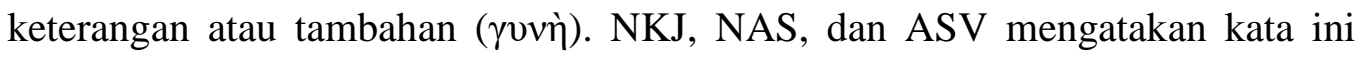
dengan arti yang sama "but the woman" (karena perempuan).

${ }^{31}$ J.Wesley Brill, Tafsiran Surat Timotius Dan Titus (Bandung: Yayasan Kalam Kudus, 1996), 29.

${ }^{32}$ Harrison, Tafsiran Alkitab Wycliffe.
${ }^{33}$ Keener, Bible Background Commentary. 
Kata $\dot{\varepsilon} \xi \alpha \pi \alpha \tau \eta \theta \varepsilon \tilde{\sigma} \sigma \alpha$ berbentuk kata kerja participle aorist passive nominative feminin singular yang berasal dari kata $\dot{\varepsilon} \xi \alpha \pi \alpha \tau \alpha ́ \omega$, muncul 6 kali dalam Alkitab dan kebanyakan terjemahan menafsirkannya "menipu". Fungsi dari participle adalah kata pelengkap dalam sebuah kalimat. Dalam terjemahannya NAS menerjemahkannya sebagai "menggoda", ASV menerjemahkan dengan menambah kata "menjadi pembohong", sedangkan NKJV menerjemahkan "menjadi penghasut".

Kata $\pi \alpha \rho \alpha \beta \alpha ́ \sigma \varepsilon ı$ (pelanggaran hukum) berasal dari kata dasar $\pi \alpha \rho \alpha ́ \beta \alpha \sigma ı \varsigma$ merupakan kata benda datif. Bentuk datif berfungsi mendeskripsikan kata benda

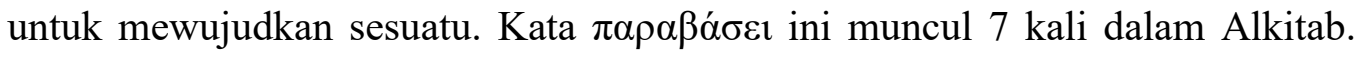
Kata parabasei ini secara harfiahnya dapat diterjemahkan "pelanggaran hukum". ITB memberi arti "jatuh ke dalam dosa". Dalam teks Yunaninya kata "pelanggaran hukum" mengandung banyak arti, namun dalam konteks ini berarti "melanggar perintah Allah". Henry menyatakan bahwa, "perempuan diciptakan untuk laki-laki dan bukan laki-laki untuk perempuan (1 Kor. 11:9). Kemudian perempuan tergoda, dan menyeret laki-laki ke dalam pelanggaran". ${ }^{34}$ Dalam kebudayaan tertentu, "dosa" hanyalah merupakan pelanggaran terhadap adat istiadat atau kebiasaan-kebiasaan setempat dan dosa yang demikian dapat dihapus melalaui tata cara kebudayaan setempat. Namun dalam Alkitab dosa adalah pelanggaran terhadap perintah Allah, dan hanya dapat diselesaikan dengan Allah. ${ }^{35}$

\section{Ananlisis Literer Teks 1 Timotius 2:15}

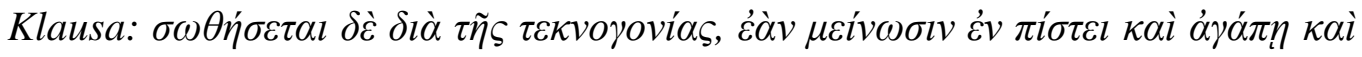
$\dot{\alpha} \gamma l \alpha \sigma \mu \tilde{\varphi} \mu \varepsilon \tau \dot{\alpha} \sigma \omega \varphi \rho o \sigma v ́ v \eta \varsigma$

Kata $\sigma \omega \theta \eta \dot{\sigma \varepsilon \tau \alpha \iota ~(u n t u k ~ m e n y e l a m a t k a n) ~ b e r b e n t u k ~ k a t a ~ k e r j a ~ o r a n g ~ k e-3 ~}$ future passive singular yang berasal dari kata $\sigma \omega \dot{\zeta} \zeta \omega$, muncul 106 kali dalam Alkitab dan kebanyakan terjemahan menafsirkan "menyelamatkan". Bentuk kata kerja ini disertakan dengan kasus future yang ditujukan kepada penderita yang bersifat obyek tidak langsung yaitu ketika surat ini ditulis dan untuk seterusnya. Sehingga dalam terjemahan ASV menerjemahkannya sebagai "tetapi ia akan diselamatkan". NAS menerjemahkan sebagai "tetapi perempuan harus dijaga melalui melahirkan anak-anak jika mereka terus dalam iman dan cinta

${ }^{34}$ Matthew Henry, Tafsiran Matthew Henry (Surabaya: Momentum, 2015), 584.

${ }^{35}$ Edward A Kotynski and M K Sembiring, Pedoman Penafsiran Alkitab Surat-Surat Paulus Kepada Timotius Dan Kepada Titus (Jakarta: Lembaga Alkitab Indonesia dan Yayasan Kartidaya, 2014), 57-58. 
dan kesucian dengan pengekangan diri”, NKJV menerjemahkan sebagai "namun demikian dia akan diselamatkan dari melahirkan anak jika mereka terus dalam iman, cinta, dan kekudusan, dengan kontrol diri”. Sedangkan BIS menerjemahkan dengan "Meskipun begitu, perempuan akan selamat dengan melahirkan anak, asal ia dengan kerendahan hati tetap percaya kepada Kristus dan tetap mengasihi orang lain serta hidup khusus untuk Allah", dan ITB menerjemahkan sebagai "Tetapi perempuan akan diselamatkan karena melahirkan anak, asal ia bertekun dalam iman dan kasih dan pengudusan dengan segala kesederhanaan".

Craig S. Kenner mengartikan sothesetai dengan, "Paul probably means "saved" or "delivered" in a different sense, however the sense it was usually given when related to childbearing. Women normally prayed to particular gods to " $\sigma \omega \theta \eta \dot{\eta} \sigma \varepsilon \tau \alpha$ " (diselamatkan) them, which meant bringing them safely through chilbirth". ${ }^{36}$ Yang artinya ialah "Paulus mengartikan "diselamatkan" atau "disampaikan" dalam arti yang berbeda, namun pengertian itu biasanya diberikan ketika berhubungan dengan melahirkan anak. Perempuan biasanya berdoa kepada dewa-dewa tertentu untuk "menyelamatkan" mereka, yang berarti membawa mereka dengan aman melalui kelahiran".

Kata benda $\tau \varepsilon \kappa v o \gamma o v i ́ \alpha \varsigma$ berasal dari kata dasar $\tau \varepsilon \kappa v o \gamma o v i ́ \alpha$ dan muncul hanya satu kali dalam Alkitab. Kasus genitif pada kata tersebut menunjukkan bahwa adalah suatu kewajiban bagi perempuan untuk melahirkan anak. Secara lisan, bacaan itu berbunyi, "Tetapi dia akan diselamatkan melalui persalinan, jika mereka terus dalam iman ..." kata kerja "selamatkan" digunakan dalam Perjanjian Baru untuk penyembuhan fisik (kebanyakan dalam Injil) dan keselamatan rohani (kebanyakan dalam surat) yang mungkin membawa konotasi di sini bahwa seorang istri dapat menemukan kesehatan jasmani dan rohani yang lebih tinggi melalui pengalaman mengasuh dan membesarkan anak-anak. Kata "melahirkan" telah memberikan banyak interpretasi kepada banyak penulis, Pertama beberapa tafsiran telah merujuk pada kelahiran Kristus, karena melalui Ia keselamatan telah datang ke dunia. Kedua, yang terkait erat dengan ini adalah interpretasi yang menghubungkan pernyataan "melahirkan anak" dengan Kejadian 3:15. Bahwa benih perempuan itu akan menghancurkan kepala ular dan membawa keselamatan bagi umat manusia. Ketiga, adalah dengan meminta kepada anak-anak sehingga dengan demikian akan memenuhi rancangan yang

${ }^{36}$ Keener, Bible Background Commentary. 
ditunjuk Allah bagi perempuan, seorang perempuan akan diselamatkan dari kejahatan sosial pada zamannya jika mengambil bagiannya di gereja lokal. ${ }^{37}$

\section{Eksegesa Sintesa 1 Timotius 2:9-15}

Berdasarkan eksegesa yang telah dilakukan dari 1 Timotius 2:9-15 di atas, mengenai maka penulis memeroleh eksegesa sintesa sebagai berikut:

Aturan Mengenai Pakaian Dan Riasan Perempuan Dalam Beribadah Tidaklah Mutlak Untuk Segala Zaman, Hanya Bersifat Menjaga Kondisi Perempuan Saat Itu.

Beberapa aturan yang berkaitan dengan cara berpakaian dan cara berdandan wanita yang terdapat dalam 1 Timotius 2:9-15 harus disikapi secara bijak. Aturan yang terdapat dalam teks ini sama sekali tidak bersifat mutlak. Peraturan di sini harus dipahami berdasarkan budaya yang ada di sekitar masyarakat dan jemaat yang dilayani oleh Timotius. Karena jika aturan tersebut dipukul rata untuk semua perempuan di segala jaman tentunya akan menimbulkan banyak masalah.

Masyarakat di mana Timotius melayani di Efesus, sebagian besar merupakan penyembah berhala. Terdapat penyembahan terhadap dewi Aprodite yang memiliki banyak pengikut baik di kota Efesus maupun dari kota-kota di sekitar. Penyembahan kepada dewi Aprodite memiliki cara ibadah yang menonjolkan kegiatan seksual yang lazim dilakukan dalam peribadahannya. Mereka juga memiliki beberapa pelacur bakti yang di taruh sebagai media beribadah dan daya tarik untuk menarik pengujung masuk kedalam kuil.

Para pelacur bakti yang terdapat dalam kuil dewi Aprodite waktu itu memiliki kebiasaan mengepang rambutnya, menggunakan pakaian yang indahindah dan mendandani dirinya sedemikian rupa. Hal ini tentunya dilakukan untuk menarik perhatian orang-orang agar mau memasuki kuil dan beribadah.38 Inilah yang menjadikan Paulus melarang perempuan-perempuan Kristen menggunakan dandanan yang berlebih, mengepang rambut dan berpakaian yang mahal-mahal.

Ditakutkan jika perempuan-perempuan kristiani melakukannya dalam beribadah, maka beberapa orang dapat terjebak anggapan bahwa budaya para perempuan Kistiani layaknya pelacur bakti yang terdapat dalam kuil-kuil dewi Artemis. Pada dasarnya Paulus sedang menjaga penilaian negatif orang-orang dengan keberadaan perempuan-perempuan Kristen. Dengan larangan yang

\footnotetext{
${ }^{37}$ Barker and Kohlenberger III, NIV Bible Commentary.

${ }^{38} \mathrm{https} / / / \mathrm{www} . b b c . c o m /$ indonesia/vert-cul-37778395
} 
ditulisnya sesungguhnya Paulus sedang menjaga martabat perempuan kristen yang sedang beribadah.

Di samping itu bagi Paulus tidak pantas bagi yang mengaku sebagai pengikut Kristus, untuk mendandani dirinya dengan berlebihan. Paulus lebih menekankan pentingnya kecantikan dari dalam dibandingkan kecantikan luar karena penggunaan dandanan dan perhiasan yang berlebihan. Apalagi penggunaan perhiasan untuk memamerkan kekayaan yang berpotensi mendatangan kesenjangan sosial dalam beribadah. Kebanggaan-kebanggaan terhadap perhiasan dan dandanan yang berlebihan juga dapat menjerat manusia terikat kepada perkara-perkara duniawi. Jika mereka adalah orang Kristen, mereka tidak perlu melakukan hal-hal kesombongan seperti itu.

Jika ditarik implikasi pada waktu sekarang yang budaya dan kondisinya sangat berbeda maka teks ini harus diterapkan dengan melihat perbandingan perbedaan konteks. Masalah pelacur bakti yang dihadapi oleh Timotius tidak lagi ditemui pada masa kini. Penggunaan riasan, perhiasan dan pakaian dengan model yang beragam bukan lagi masalah yang mengganggu dalam masyarakat saat ini. Beberapa menjadikan riasan, perhiasan dan pakaian dianggap seni dalam merias diri. Namun demikian problem kesejangan masih juga merupakan keadaan yang mudah ditemui saat ini dalam gereja. Menghindari semakin meruncingnya kesenjangan dalam umat Tuhan yang sedang beribadah, adalah bijak untuk menasehati umat khususnya berkaitan dengan perhiasan, agar jemaat dapat menggunakan perhiasan secara tidak berlebihan saat pelaksanaan ibadah. Bukan larangan secara mutlak, namun hanya sebuah himbauan agar tidak mendatangkan kecemburuan sosial.

\section{Aturan Perempuan Berdiam Diri, Dan Tidak Mengajar Bukanlah Karena} Pembedaan Gender Melainkan Karena Kondisi Budaya Waktu Itu.

Peraturan mengenai diamnya perempuan dalam pertemuan ibadah seringkali dianggap sebagai legitimasi bahwa perempuan sejak semula tidak diijinkan mengajar. Namun jika dilihat dengan latar belakang teks hal itu tidaklah benar. Perlu diingat bahwa kondisi budaya saat itulah menjadikan aturan ini perlu ada. Teks ini sama sekali bukanlah dukungan terhadap pembedaan gender laki-laki dan perempuan.

Pada masa itu perempuan tidak mendapatkan pendidikan layaknya lakilaki. Kebanyakan pendidikan keagamaan hanya ditujukan kepada kaum pria semata. Mengingat akan hal ini sangatlah berbahaya memberikan tugas pengajaran dalam ibadah kepada perempuan yang tidak terdidik dalam ajaran- 
ajaran agama. Masalah disini bukanlah pada gender perempuan yang menjadikan mereka tidak bisa mengajar. Melainkan masalah yang paling mendasar adalah ketidakmampuan perempuan mengajar karena mereka sendiri tidak terdidik dalam hal tersebut.

Dalam mengajar sudah pasti sang pengajar membutuhkan keterampilan dan pengetahuan yang baik mengenai ajaran agama. Seandainya seseorang yang tidak terdidik dalam ajaran iman dan memaksakan diri untuk mengajar hal ini tentu saja akan menimbulkan kesesatan. Inilah yang sedang dihindari Paulus dalam aturannya perempuan harus berdiam diri waktu beribadah.

Jika diterapkan pada saat ini, banyak perempuan-perempuan yang mendapatkan pendidikan agama yang baik dalam sekolah teologi, maupun sekolah alkitab yang ada. Sudah tentu bagi mereka yang telah terdidik dalam ajaran iman, kesempatan harus dibuka supaya mereka dapat memberikan pengajaran kepada umat. Asalkan sudah terdidik, perempuan maupun laki-laki memiliki kesetaran hak untuk mengajar dalam ibadah.

\section{Aturan Ketundukan Dan Larangan Memerintah Pria Mengarahkan Perempuan}

\section{Untuk Mengerti Perannya Dalam Keluarga.}

Paulus tidak mengizinkan perempuan untuk mengambil hak laki-laki atau memerintah laki-laki, baik dalam jemaat ataupun dalam rumah tangga. Paulus menghendaki seorang laki-laki yang mengambil bagian terbesar dalam kebaktian jemaat dan dalam hal mengajar jemaat, sedangkan perempuan harus berdiam diri. 39 Kata "berdiam diri" di sini bukan berarti "bisu" atau tidak mengatakan apapun dalam peribadatan, perempuan diperkenankan untuk berbicara namun perempuan harus merendahkan diri. Sehingga Paulus memerintahkan perempuan untuk tidak mengambil bagian laki-laki atau memerintah laki-laki.

Jadi perempuan seharusnya "menerima ajaran" dan bukan "mengajar", sebab mengajar dalam jemaat adalah hak khusus bagi kaum laki-laki. Hal ini menandai keadaan jemaat Kristen mula-mula pada masa itu yang membedakannya dari rumah ibadat orang Yahudi di mana pengajaran hanya diberikan kepada kaum laki-laki dan anak laki-laki. Sejak awal gerakan Kristen, kaum perempuan diikutsertakan dalam pengajaran bersama-sama dengan kaum

\footnotetext{
${ }^{39}$ Brill, Tafsiran Surat Timotius Dan Titus.
} 
laki-laki dengan suatu syarat yaitu perempuan harus belajar dengan "berdiam diri" yang artinya dalam pertemuan jemaat tidak diijinkan untuk berbicara. ${ }^{40}$

Akhirnya, para perempuan harus "patuh" dan tidak boleh "memerintah laki-laki". Dalam ungkapan "patuh" tercakup hal penghargaan, tunduk dan kepatuhan. Hal tersebut berarti bahwa perempuan harus tunduk kepada wewenang kaum laki-laki sebagai pengajar dan menerima segala yang diajarkan kepada mereka dengan rendah hati dan patuh. Berdasarkan hal ini maka sangat masuk akal jika perempuan diharapkan untuk tidak mengajar laki-laki atau memerintah mereka. Di sini kata "memerintah" berarti mengendalikan, menguasai, dan mengendalikan dengan cara menguasai. ${ }^{41}$ maat. Demikianlah ajaran Paulus yang terutama bagi istri. Mereka harus tunduk kepada suami. Sebagai perempuan yang ada di dalam Tuhan setiap istri harus tunduk kepada suaminya. Sikap tunduk dalam bentuk siap merendahkan diri dan sadar bahwa laki-laki adalah kepala mereka; sebagai sumber keberadaan mereka. ${ }^{42} \mathrm{Hal}$ ini berarti secara tidak langsung menunjukkan tidak adanya diskriminasi antara laki-laki dengan perempuan.

\section{Simpulan}

Berdasarkan analisis teks 1 Timotius 2:9-15, maka perempuan maupun laki-laki memiliki kesamaan hak dalam peribadatan. Pembatasan terhadap peran perempuan dalam peribadatan pada I Timotius 2:9-15 terjadi karena keadaan budaya yang ada pada masa itu. Paulus sama sekali tidak menganggap derajat perempuan lebih rendah dibandingkan laki-laki, sehingga perempuan dibatasi perannya dalam peribadatan. Pada dasarnya laki-laki dan perempuan memiliki hak yang sama terlibat dalam pelayanan peribadatan. Laki-laki maupun Perempuan wajib menjaga etika dan norma-norma yang berlaku. Seperti perempuan harus berpakaian sopan, rendah hati, bijaksana, dan patuh kepada suami. Perilaku dan cara berpakaian harus sopan dan sewajarnya seseorang pelayan Tuhan.

${ }^{40}$ Daniel C Arichea and Howard A Hatton, No Title (Jakarta: Yayasan Karunia Bakti Budaya Indonesia, 2014), 56.

${ }^{41}$ Arichea and Hatton, No Title.

${ }^{42}$ Randy Frank Rouw dan Julian Frank Rouw, Paulus dan Perempuan (Journal Jaffray Vol 12 No.2, 2019) 176. 


\section{Daftar Pustaka}

Arichea, Daniel C, and Howard A Hatton. No Title. Jakarta: Yayasan Karunia Bakti Budaya Indonesia, 2014.

Barker, Kenneth L, and John R Kohlenberger III. NIV Bible Commentary. USA: Zondervan Publishing House, 1994.

Brill, J.Wesley. Tafsiran Surat Timotius Dan Titus. Bandung: Yayasan Kalam Kudus, 1996.

Clouse, Robert G. Women In Ministry: Four Views. Illinois: Intervarsi1y Press Downers Grove, 1999.

Harrison, Everett F. Tafsiran Alkitab Wycliffe. Malang: Gandum Mas, 2001.

Henry, Matthew. Commentary In One Volume. USA: Regency Reference Library, 1961.

—. Tafsiran Matthew Henry. Surabaya: Momentum, 2015.

Keener, Craig S. Bible Background Commentary. USA: Iter Varsity Press, 1993. Kotynski, Edward A, and M K Sembiring. Pedoman Penafsiran Alkitab Surat-

Surat Paulus Kepada Timotius Dan Kepada Titus. Jakarta: Lembaga

Alkitab Indonesia dan Yayasan Kartidaya, 2014.

Maryono, Petrus. Analisis Retoris. Yogjakarta: Andi, 2017.

Newel, Lyne. Bahasa Yunani Koine. Malang: SAAT, 1987.

Panjaitan, Firman. "Kekerasan Terhadap Istri Dalam Lingkup Domestik (Suatu Tinjauan Etis Kristiani Tentang Kekerasan Terhadap Keluarga)." FIDEI:

Jurnal Teologi Sistematika dan Praktika 1, no. 1 (2018): 42-67.

Stern, David H. Jewish New Testament Commentary. USA: Jewish New Testament Publications, 1992.

_ Jewish New Testament Commentary. USA: Jewish New Testament Publications, INC, 1996.

Suawa, Ferdinan. Memahami Gramatika Dasar Bahasa Yunani Koine. Bandung:

Kalam Kudus, 2009.

Subagyo, Andreas B. Pengantar Riset Kualitatif Dan Kuantitatif. Bandung: Yayasan Kalam Hidup, 2004.

Wicaksono, Arif, and Dwi Anggono. "Yesus, Hamba Allah Yang Menderita." FIDEI: Jurnal Teologi Sistematika dan Praktika 2, no. 1 (2019): 142-158. https://www.bbc.com/indonesia/vert-cul-37778395. https://www.studylight.org/commentaries/bnb/1-timothy-2.html. https://www.studylight.org/commentaries/hmc/1-timothy-2.html. 